\title{
Survival of Prey DNA inside A Crocodile Gut: A Review of Crocodilian Gastric Function and Accompanying Gastric Assault
}

\author{
Lay-Hong Seah*, Zaliha Suadi and Boon-Hui Wee \\ Department of Chemistry Malaysia, Kuching Branch, Malaysia
}

Submission: August 20, 2017; Published: August 24, 2017

*Corresponding author: Lay-Hong Seah, Department of Chemistry Malaysia, Kuching Branch, Lot 3148, Block 14, Jalan Sultan Tengah, 93050 Petra Jaya, Kuching, Malaysia, Tel: (60)082-313011; Email: lhseah@kimia.gov.my

\begin{abstract}
Examination of the stomach contents of the human scavenging crocodile becomes forensically relevant in the event the missing victim is suspected to fall prey to the carnivore. The exhaustive digestion and harsh acidic stomach of the crocodile is expected to severely compromise the quality and quantity of amplifiable DNA from the remains of the prey. This paper reviewed the physiological events in the stomach of the vertebrate carnivore and the survival of bone DNA from the gastric assault. A case study involving a missing villager suspected to fall prey to a crocodile was tracked to the bones recovered from the stomach of a killed crocodile. DNA genotyping of the bone remains revealed partial profiles by standard STR typing and reinforced the expectation that bone DNA is severely compromised by the harsh digestive enzymes and gastric acid. The utility of a more sensitive DNA identification system such as the AmpFISTR® MinifilerTM Amplification Kit is necessary for DNA identification of the skeletal remains inside a crocodile gut.
\end{abstract}

Keywords: Crocodile's stomach; Bone DNA; Crocodile physiology

\section{Introduction}

Crocodilians gulp their food in large pieces, including bones with little mechanical breakdown. The main reduction in size and chemical degradation of the feed occurs at the level of the stomach [1]. The main physiological events in the stomach of the scavenging carnivores comprises of

a) Secretion of highly concentrated hydrochloric acid,

b) Secretion and activity of proteolytic enzymes and

c) Rhythmic contractions [2,3].

The highly concentrated hydrochloric acid $(\mathrm{pH}<2)[4]$ provides an adequate ambience for the action of the digestive enzymes [5]. The acid also serves as a primary agent for the degradation of bones and other hard structures included in the diet such as calcareous exoskeletons and shells [6].

A sterilizing effect through inhibition and/or destruction of putrefying bacteria is also attributed to the acid secretion [7]. The pepsins present in the stomach and other digestive enzymes along the digestive tract further degrade the food mass. Gastric contractions assures faster contact of the food mass with the enzyme secretions and further enhances the grinding effects of gastroliths found in the lumen of the stomach of some reptiles like the crocodile $[4,8]$. A post-mortem carried out on a crocodile uncovered bone remains in the crocodile's stomach. There was considerable difficulty encountered in DNA genotyping of the bones for successful identification of the prey. This review also focuses upon bone degradation by chemical deterioration in the crocodile's gut and the impact upon the survival of biomolecules like DNA in the bone.

\section{Materials and Method}

Five pieces of bone were submitted to the Department of Chemistry Malaysia Forensic DNA laboratory in Kuching, Sarawak after a post-mortem was carried out on a crocodile. DNA extraction was carried out using the standard phenol/chloroform protocol. There were detectable amounts of DNA for only two of the bone pieces when quantified by Quantifiler ${ }^{\mathrm{TM}}$ Human DNA Quantification Kit. Only one bone piece yielded amplifiable amount of DNA. STR (Short Tandem Repeats) amplifications 
were carried out in $20 \mu \mathrm{l}$ reaction volumes using the maximum possible DNA template with three types of PCR markers kits namely, AmpFISTR $₫$ Identifiler $\AA$ Plus, AmpFlSTR $₫$ Yfiler $\AA$ and AmpFISTR $\AA$ MinifilerTM. The amplicons were separated on Applied Biosystems 3130xl Genetic Analyzer using GeneMapper ID v3.2.1 software. A detection threshold limit of $50 \mathrm{rfu}$ was used to designate alleles.

\section{Results and Discussion}

Only one piece of bone had amplifiable amounts of DNA to yield partial DNA profiles with the AmpFISTR $®$ Identifiler $\AA$ Plus and AmpFISTR $\AA$ Yfiler ${ }^{\circledR}$ Amplification Kits. DNA genotyping failed with the other four pieces of bone. A complete profile at 16 STR loci was successfully obtained on further amplification of the bone DNA extract with the AmpFISTR® MinifilerTM PCR kit. Clearly, bone mineral (hydroxyapatite) is in profound disequilibrium with the acidic environment in the crocodile's digestive tract. Under extreme low $\mathrm{pH}$ conditions that exist in the crocodile's gut, the first fateful step in the deterioration of the mineral phase takes place [9]. There occurs dissolution of the mineral phase of the bone. Removal of the mineral phase permits access to the bone collagen by digestive enzymes leading to accelerated chemical and biological degradation of the bone. However, the high acidity in the stomach might retard microbial attack [7].

The chemical deterioration of the bone mineral and collagen leads to deterioration of the protective bone matrix which houses biomolecules such as cellular lipids and DNA within the physiological spaces within bone. Acid hydrolysis of DNA proceeds by depurination of DNA which leads to destabilization of the phophodiester bond of the DNA backbone resulting in strand breaks [10]. Fragmentation of bone DNA by acid assault in the crocodile's gut is evident when standard STR typing failed for the larger amplicons in the AmpFISTR $®$ Identifiler $®$ Plus and AmpFISTR $®$ Yfiler $®$ marker systems. The use of mini-STRs that targets the larger loci successfully amplified the DNA from the compromised DNA.

The exhaustive digestion and harsh acidic stomach of the crocodile is expected to severely compromise the quality and quantity of amplifiable DNA from the remains of the prey. Tough and hardy biological materials such as bone with its protective hard matrix are not spared from the gastric assault. The availability of robust DNA typing markers and technology today like mini STRs and SNPs can provide solutions for successful identification of the compromised skeletal remains.

\section{References}

1. Wilson JA (1972) Principles of Animal Physiology, MacMillan Press, New York, USA.

2. Davenport HW (1971) Physiology of the Digestive Tract ( $3^{\text {rd }}$ edn). Year Book Medical Publishers, Chicago, USA.

3. Code CF, Carlson HC (1968) Motor Activity of the stomach. In Handbook of Physiology Am Physiol Soc, Washington, USA, 6(4): 93.

4. Davson H (1970) A Textbook of General Physiology (4 ${ }^{\text {th }}$ edn). Williams and Wilkins, Baltimore, USA.

5. Gordon MS, Bartholomew GA, Grinnel AD, Jorgensen CB, White FN (1972) Animal Physiology: Principles and Adaptations, Macmillan, New York, USA.

6. Coulson RA, Hernandez T (1964) Biochemistry of the Alligator, Louisiana State University Press, Louisiana, USA.

7. Smit H (1968) Gastric secretion in the lower vertebrates and birds. In Handbook of Physiology, Am. Physiol Soc, Washington, USA.

8. Taylor MA (1993) Stomach stones for feeding or buoyancy? The occurrence and formation ofm gastroliths in marine tetrapods, Philosophical Transactions of the Royal Society of London. Series B: iological Sciences, 341 (1296): 163-175.

9. Collins MJ, Nielsen-Marsh CM, Hiller J (2002) The Survival of Organic Matter in Bone: A Review, Archaeometry 44(3): 383-394.

10. Lindahl $T$ (1993) Instability and decay of the primary structure of DNA, Nature 362: 709-715.
This work is licensed under Creative Commons Attribution 4.0 License DOI: $10.19080 / J F S C I .2017 .04 .555642$
Your next submission with Juniper Publishers will reach you the below assets

- Quality Editorial service

- Swift Peer Review

- Reprints availability

- E-prints Service

- Manuscript Podcast for convenient understanding

- Global attainment for your research

- Manuscript accessibility in different formats ( Pdf, E-pub, Full Text, Audio)

- Unceasing customer service

Track the below URL for one-step submission https://juniperpublishers.com/online-submission. 